\title{
Type 2 Diabetes Mellitus
}

\author{
Xuan Yi Sim ${ }^{1,2}$ and Lay-Harn Gam*1,2 \\ ${ }^{1}$ School of Pharmaceutical Sciences, Universiti Sains Malaysia, Malaysia \\ ${ }^{2}$ USM-RIKEN Centre for Ageing Science (URICAS), Universiti Sains Malaysia, Malaysia
}

Submission: October 01, 2017; Published: October 05, 2017

*Corresponding author: Lay-Harn Gam, School of Pharmaceutical Sciences, Universiti Sains Malaysia, Minden 11800 Penang, Malaysia, Tel: +6046532208; E-mail: layharn@usm.my

\section{Mini Review}

The incidence of diabetes mellitus (DM) is increasing particularly in the developing nation. It is also one of the major global public health problems. The World Health Organization (WHO) predicts that over 330 million people worldwide will have DM and around $5-10 \%$ of national health care budget are estimated to be allocated for DM alone by 2030 WHO [1]. DM also is closely related to the increase of premature and preventable death. The number of death attributed directly or indirectly to DM has reached 3.7 million in 2012 WHO [2]. The chronic hyperglycaemia (an abnormally high amount of glucose level in blood) of diabetes is associated with long-term damage, dysfunction, and failure of various organsand other macro and microvascular diseases, such as end-stage renal failure, blindness, heart disease, stroke, dementia and leg amputation Cade [3]; WHO [2].

There are two types of DM namely Type 1 diabetes and Type 2 diabetes mellitus (T2DM).T2DM is a more prevalence type (85 $\%$ of people with DM) which causes by heterogeneous disorder involving progressive development of insulin resistance in liver and peripheral tissues accompanied by defective insulin secretion from pancreatic beta cells that leads to hyperglycemia. Despite the genetic predisposition, the risk of developing T2DM is increased with age, obesity and lack of physical activity.

$90 \%$ of patients with T2DM are obese or overweight. This makes obesity and overweight the leading factor of the increase of T2DM WHO [4]. Obesity and overweight happen when the calories intake is higher than the calories expended. High fat diet which is energy dense easily caused overweight and obesity WHO [5]. T2DM patients can improve their outcomes through healthy living by combination of diet and physical activity. As we observed the eating habits of a group of diabetic patients, we found that although many of the patients was able to abide to a tight control on diet, many more do not many delicacies are with high fat content. However, the exact mechanism linking high fat diet and diabetes still remain on high debate especially with the risen popularity of the low carbohydrate high fat diet Gunnarsson and Elam [6].

Metabolic profiling is able to give an instantaneous snaphot of the physiology of cell as metabolites are the end products of cellular processes Jordan et al. [7]. It is expected that diabetes will perturb several metabolic processes including enery metabolism and nucleotide metabolsim. The end products, N-methylnicotinamide and N-methyl-2-pyridione-5-carboxiamide (2PY) of nucleotide metabolism has be detected in great quantity in diabetic mouse, rat and human Salek et al. [8] N-methylnicotinamide has been implied to exert antithrombotic and anti-inflammatory effects through direct action on the endothelium which may induce vasorelaxation in human blood vessels Domaagala et al. [9]. On the other hand, 2PY has been suggested to be a uremic toxin that deteriorates kidney function Lenglet et al. [10]. Hence, the effect of these two compounds on human health is contradictory. Hence, the effect of changes of metabolites profile in diabetic patients is yet to be investigated.

\section{References}

1. WHO (2010) Facts and figures about diabetes. World Health Organization

2. WHO (2016 a) Global report on diabetes.

3. Cade WT (2008) Diabetes-Related Microvascular and Macrovascular Diseases in the Physical Therapy Setting. Physical Therapy 88(11): 1322-1335.

4. WHO (2013) Obesity and Overweight. World Health Organization.

5. WHO (2016 b) Obesity and overweight Fact sheet. World Health Organization.

6. Gunnarsson A, Elam M, (2012) Food Fight! The Swedish Low-Carb/ High Fat (LCHF) Movement and the Turning of Science Popularisation Against the Scientists. Science as Culture 21(3): 315-334.

7. Jordan KW, Nordenstam J, Lauwers GY, Rothenberger DA, Alavi $\mathrm{K}$, et al. (2009) Metabolomic Characterization of Human Rectal Adenocarcinoma With Intact Tissue Magnetic Resonance Spectroscopy. Diseases of the colon and rectum 52(3): 520-525. 
8. Salek RM, Maguire ML, Bentley E, Rubtsov DV, Hough T (2007) A metabolomic comparison of urinary changes in type 2 diabetes in mouse, rat, and human. Physiological Genomics 29(2): 99-108.

9. Domagala TB, Szeffler A, Dobrucki LW, Dropinski J, Polanski S, et al. (2012) Nitric Oxide Production and Endothelium-Dependent
Vasorelaxation Ameliorated by N1-Methylnicotinamide in Human Blood Vessels. Hypertension.

10. Lenglet A, Liabeuf S, Bodeau S, Louvet L, Mary A, et al. (2016) N-methyl2-pyridone-5-carboxamide (2PY)-Major Metabolite of Nicotinamide: An Update on an Old Uremic Toxin. Toxins 8(11): 339.

\section{Your next submission with Juniper Publishers will reach you the below assets}

- Quality Editorial service

- Swift Peer Review

- Reprints availability

- E-prints Service

- Manuscript Podcast for convenient understanding

- Global attainment for your research

- Manuscript accessibility in different formats ( Pdf, E-pub, Full Text, Audio)

- Unceasing customer service

Track the below URL for one-step submission https://juniperpublishers.com/online-submission.php 